\title{
Do patient and practice characteristics confound age-group differences in preferences for general practice care? A quantitative study
}

\author{
Willemijn A de Graaf-Ruizendaal ${ }^{1 *}$, Annette J Berendsen ${ }^{2}$, Dolf de Boer ${ }^{3}$ and Dinny H de Bakker ${ }^{1,4}$
}

\begin{abstract}
Background: Previous research showed inconsistent results regarding the relationship between the age of patients and preference statements regarding GP care. This study investigates whether elderly patients have different preference scores and ranking orders concerning 58 preference statements for GP care than younger patients. Moreover, this study examines whether patient characteristics and practice location may confound the relationship between age and the categorisation of a preference score as very important.

Methods: Data of the Consumer Quality Index GP Care were used, which were collected in 32 general practices in the Netherlands. The rank order and preference score were calculated for 58 preference statements for four age groups (0-30, 31-50, 51-74, 75 years and older). Using chi-square tests and logistic regression analyses, it was investigated whether a significant relationship between age and preference score was confounded by patient characteristics and practice location.
\end{abstract}

Results: Elderly patients did not have a significant different ranking order for the preference statements than the other three age groups $(r=0.0193 ; p=0.41)$. However, in 53\% of the statements significant differences were found in preference score between the four age groups. Elderly patients categorized significantly less preference statements as 'very important'. In most cases, the significant relationships were not confounded by gender, education, perceived health, the number of GP contacts and location of the GP practice.

Conclusion: The preferences of elderly patients for GP care concern the same items as younger patients. However, their preferences are less strong, which cannot be ascribed to gender, education, perceived health, the number of GP contacts and practice location.

Keywords: Preferences, Elderly, GP care

\section{Background}

In the next 30 years, an increase in the demand for primary care is to be expected due to an ageing population [1-3]. Already, elderly patients have a substantially higher contact rate with general practice care than younger patients [4]. Primary health care must be able to adapt to the health care needs of the elderly, which are different from younger patients, to ensure the well-being of older people [1].

\footnotetext{
* Correspondence: w.ruizendaal@nivel.nl

${ }^{1}$ Department of primary care organization, NIVEL: Netherlands Institute for Health Service Research, PO Box 1568, 3500 BN Utrecht, The Netherlands Full list of author information is available at the end of the article
}

Moreover, primary care should address the preferences and the views of older patients [1,5], as differences in health care needs may lead to differences in preferences regarding health care [6]. Indeed, De Boer et al. found that patient groups categorised by health problem differed in their preferences for quality aspects of care [7]. Greater insight into elderly people's preferences regarding primary care can help to make primary care more responsive to the needs of the elderly $[5,6]$.

Substantial research has been conducted into the preferences of patients regarding quality aspects of GP care $[5,6,8-13]$. The influence of age on the preferences regarding GP care showed different magnitudes [6,9,10]. Moreover, one study did not find any relationship between age

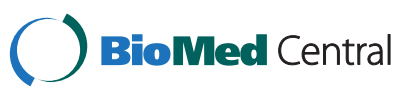


and preference scores. This study concluded that the results for patients' preferences are mixed and that 'the reason for this is unclear and may relate to a number of factors' [11].

Even though the outcomes regarding the influence of age on preference scores differ widely, little research has been conducted into the factors which may influence these differences. In a Dutch study, Jung et al. stated that it was not age but the number of GP contact moments which had the greatest influence on preference scores. Other direct effects on preference scores were found for level of education, gender, and health status [9]. In addition to age, a systematic literature review identified a direct effect on preferences of level of education, health status, gender, family situation and utilisation of health care services [6]. Despite these direct effects on preference scores, the review did not elaborate on the possible effects on the relationship between age and preferences. To our knowledge, only two studies have elaborated on the influence of some of the above factors on the relationship between age and preference score $[10,12]$. However, they did so only for three preference statements regarding GP care.

In this study, we investigate whether elderly patients have different preferences concerning 58 preference statements for GP care than younger patients and examines whether gender, education, perceived health, health care use and degree of urbanisation may confound the relationship between age en preference score. These characteristics have been shown to have a major influence on the preferences for GP care $[6,9]$. The relationship between age and preferences regarding GP care is of special interest because older patients are more dependent on others, have a higher health care use, have a lower health status, and suffer more from chronic diseases than younger patients [3].

\section{Methods}

\section{Data collection and response}

Data of the Consumer Quality Index GP care (CQI GP care) were used, which were collected for the development of this instrument between 2005-2007 in 32 GP practices in the Netherlands with a total of more than 16,000 patients [14]. The practices involved were located in both rural and urban areas. Every resident in the Netherlands is registered with a GP. For all patients registered at one of these practices, name, address, date of birth and gender were extracted. Using random sampling a questionnaire was sent in name of the GP to patients from every GP practice $(n=32)$. One practice was situated in an disadvantage area. To compensate for the expected low response rate for this practice, 150 questionnaires were sent. One practice had a very small patient population and therefore no questionnaires were sent. The total amount of questionnaires sent was $\mathrm{n}=3,150$.

The CQI is a Dutch valid instrument to measure patient experiences and preferences regarding health care [15]. It is based on two other types of surveys: the American CAHPS (Consumer Assessment of Healthcare Providers and Systems) [16,17] and the Dutch QUOTE (QUality Of care Through the patients' Eyes) [18-20]. The CQ-index is characterized by its disease-specific and provider-specific focus as well as the assessment of patient priorities, which both derive from the QUOTE. The lay-out, response scales and standardized sampling, data collection, analysis and presentation adopted for the QC-index were taken from CAHPS. The CQ-index has been declared to be the national standard for measuring patient experiences and performance indicators of quality of care are frequently based on the CQindex $[21,22]$.

The questionnaire contained questions regarding the respondents' characteristics according to the CQI method [15] and 58 preference statements regarding GP care and the other health care providers (OHCP) in the GP practice, such as the practice nurse. The statements covered subjects such as communication, accessibility, affection, care from other health care providers such as an assistant, specialised or diabetes nurse and/or practice nurse), organisation, patient-centred care, cooperation and expertise [14]. Patients could answer on a four-point scale which ranged from 'not important', 'reasonable important', 'important' to 'very important'. To address avoidance of scale extreme, especially amongst the oldest age group, the response scale are small and value labels were added to the response categories.

The questionnaire was filled in both by patients who had and by patients who had not visited a GP in the previous year. Despite the fact that those patients did not visit the GP in the previous year, they presumably have experiences with visiting the GP and therefore their preferences regarding GP care remain relevant and important.

\section{Statistical analysis}

Patients were categorised in four age groups (0-30, 30-51, 51-75 and 75 years and older). Subsequently, a rank order was calculated for every preference statement based on the mean score of the preference statements for every age group (scores 1-4). Next, the percentage of patients who found a preference statement 'very important' (preference score) was calculated for every preference statement for the four age groups. Therefore, the 58 preference statements were dichotomised ( 0 = 'not very important' to' important', 1 = 'very important'). The mean number of statements which were categorized as 'very important' was calculated for every age group. Using Students' t-test it was 
calculated whether the mean preference score differed significantly between the age groups and with spearman correlation the association between the different age groups and the rank order was calculated.

To analyse whether there were significant differences in the percentage of patients who found a statement 'very important' (preference score) between the four age groups, a chi-square test was conducted for every statement $(n=58)$. To analyse which age groups differed significantly on 'preference score', the chi-square tests were repeated for the statements with a significant $p$-value $(p<0.05)$ for every possible combination of two age groups.

Subsequently, logistic regression was used to analyse whether there was still a significant relationship between age and preference score after gender $(1=$ female $)$ and education ( $1=$ low, 2 = average, $3=$ high), perceived health $(0=$ less than good health and $1=$ good health $)$ and GP contact $(0=$ less than 5 contact moments and $1=5$ or more contact moments), and degree of urbanisation $(0=$ rural, $1=$ urban $)$ had been entered. If in the fourth model there was still a significant relationship between age and preference score, we defined that the above-mentioned factors did not confound the significant relationship between age and preference score. We were interested on the effects of the factors on the relationship between age and preference score and not on their main effects. The analyses were carried out using STATA (version 10, 2009, STATACorp, College Station Texas).

\section{Results}

\section{Response and demographics of the subgroups}

The number of questionnaires sent amounted to 3,150. A total of 89 questionnaires were returned undeliverable. The net response was $60.7 \%(n=1,858)$. For 35 respondents age was unknown and they were therefore excluded from the analysis $(\mathrm{n}=1,823)$. The patient characteristics and the practice characteristic for the four age groups are shown in Table 1. For the four age groups, the chi-square tests showed significant differences in education $(p<0.001)$, gender $(p<0.001)$, perceived health $(p<0.001)$, number of GP contacts $(p<0.001)$ and urbanisation of the practice location $(p<0.001)$.

\section{Preference scores and rank order}

Table 2 shows the different preference statements $(n=58)$, the percentage of respondents from the four age groups who found the preference statements 'very important', the rank order and significant differences between the age groups in the preference scores. The preference statements were ranked according to the rank score of the patient group ' 75 years and older'. In general, the preference statements with the ten highest and lowest scores were the same for the four age groups. There was no significant difference in rank order between the four age groups. According to the Spearman rank test, the relationship between the respondents' age and the mean score given to the preference statements was non-significant $(r=0.0193 ; p=0.41)$. The preference statements with the three highest scores for patients '75 years and older' were 'good expertise of GP', 'no conflicting information from OHCP and GP' and 'good cooperation between OHCP and GP'.

The chi-square tests showed a significant difference in preference score between two or more different age groups for $53.4 \%(n=31)$ of the preference statements. In most cases, patients ' 75 years and older' had the lowest preference score. The results of the chi-square tests, which compare two groups separately, showed for the group of ' $0-30$ years old', the most significant differences in preference scores $(n=26)$ with the group of '75 years and older'. For the group of '30-50 years old', the most significant differences $(n=28)$ were also with the group '75 years and older' and the same yields for the group of '50-75 years old' $(n=23)$.

Table 3 shows the mean number of preference statements which are categorised as 'very important' for the different age groups. The results showed that the group of '50-75 years old' had the largest number of preference statements which were categorised as 'very important' (mean $=18.1$ ) and the group of '75 years and older' had the lowest mean number of preference statements that were categorised as 'very important' $($ mean $=14.2)$. This difference was significant $(t(688)=3.13 ; p<0.001)$.

\section{Logistic regression; controlling for gender, education, perceived health, GP contacts and urbanisation of the practice location}

Logistic regressions were conducted for the 31 statements for which the chi-square tests showed a significant difference in the preference scores between the age groups. For most of the statements, the significant relationship between age and preference score did not disappear after the confounders were entered in the logistic regression model. The significant influence of age on preference score disappeared for only five statements after entering the factor education; most of these preference statements concerned the other health care provider. Table 4 shows the five preference statements for which the significant relationship disappeared. The other confounder variables; perceived health, number of GP contacts and GP practice location did not influence the significant relationship between age and preference score.

\section{Discussion}

Health care for the elderly has become an essential part of GP care. In the future, the number of elderly patients 
Table 1 Patient and practice characteristics for the respondents $(n=1823)$ in the four age groups

\begin{tabular}{|c|c|c|c|c|c|c|c|c|}
\hline \multirow[b]{2}{*}{ Mean age } & \multicolumn{2}{|c|}{$\begin{array}{l}\text { Patients } 0-30 \text { years } \\
(n=283)\end{array}$} & \multicolumn{2}{|c|}{$\begin{array}{l}\text { Patients } 30-51 \text { years } \\
(\mathrm{n}=633)\end{array}$} & \multicolumn{2}{|c|}{$\begin{array}{l}\text { Patients } 51-75 \text { years } \\
(\mathrm{n}=700)\end{array}$} & \multicolumn{2}{|c|}{$\begin{array}{l}\text { Patients } 75 \text { years and older } \\
(n=207)\end{array}$} \\
\hline & 21.4 & $\mathrm{SD}=6.3$ & 40.8 & $\mathrm{SD}=5.9$ & 60.8 & $\mathrm{SD}=6.5$ & 80.74 & $\mathrm{SD}=4.4$ \\
\hline & $\mathrm{n}$ & $\%$ & $n$ & $\%$ & $n$ & $\%$ & $\mathrm{n}$ & $\%$ \\
\hline \multicolumn{9}{|l|}{ Education } \\
\hline - unknown & 14 & 5.0 & 17 & 2.7 & 47 & 6.7 & 21 & 10.1 \\
\hline - low & 84 & 29.7 & 152 & 24.1 & 300 & 42.9 & 128 & 61.8 \\
\hline - medium & 128 & 45.2 & 259 & 46.6 & 256 & 36.6 & 47 & 22.7 \\
\hline - high & 57 & 20.1 & 169 & 26.7 & 97 & 13.9 & 11 & 5.3 \\
\hline \multicolumn{9}{|l|}{ Gender } \\
\hline - unknown & 2 & 0.7 & 0 & 0 & 1 & 0.1 & 0 & 0 \\
\hline - male & 182 & 64.3 & 223 & 35.2 & 319 & 45.6 & 70 & 33.8 \\
\hline - female & 99 & 34.9 & 410 & 64.8 & 380 & 54.3 & 137 & 66.2 \\
\hline \multicolumn{9}{|c|}{ Perceived health } \\
\hline - unknown & 0 & 0 & 6 & 0.9 & 13 & 1.9 & 2 & 1.0 \\
\hline - bad & 2 & 0.7 & 13 & 2.1 & 22 & 3.1 & 8 & 3.9 \\
\hline - reasonable & 27 & 9.5 & 94 & 14.8 & 176 & 25.1 & 85 & 41.1 \\
\hline - good & 156 & 55.1 & 377 & 59.6 & 409 & 58.4 & 100 & 48.3 \\
\hline - very good & 66 & 23.3 & 106 & 16.7 & 57 & 8.1 & 10 & 4.8 \\
\hline - excellent & 32 & 11.3 & 37 & 5.8 & 23 & 3.3 & 2 & 0.1 \\
\hline \multicolumn{9}{|c|}{ GP contact rate } \\
\hline - unknown & 8 & 2.8 & 27 & 4.3 & 52 & 7.4 & 15 & 7.2 \\
\hline-0 & 55 & 19.4 & 68 & 10.7 & 82 & 11.7 & 11 & 5.3 \\
\hline-1 & 51 & 18.0 & 94 & 14.8 & 82 & 11.7 & 9 & 4.3 \\
\hline$-2-4$ & 108 & 38.2 & 254 & 40.1 & 243 & 34.7 & 55 & 26.6 \\
\hline$-5-9$ & 51 & 18.1 & 144 & 22.7 & 166 & 23.7 & 81 & 39.1 \\
\hline - 10 or more & 10 & 3.5 & 146 & 7.3 & 75 & 10.7 & 36 & 17.4 \\
\hline \multicolumn{9}{|c|}{ Urbanisation practice location } \\
\hline - unknown & 0 & 0 & 11 & 1.7 & 23 & 3.3 & 7 & 3.4 \\
\hline - rural & 152 & 53.7 & 341 & 53.9 & 301 & 43.0 & 80 & 38.6 \\
\hline - urban & 131 & 46.3 & 281 & 44.4 & 376 & 53.7 & 120 & 58.0 \\
\hline
\end{tabular}

with complex health care needs as a result of multimorbidity, disability, vulnerability, and loss of control will grow $[13,23,24]$. Despite the complex health care needs of elderly patients, the present study showed no significant difference in the rank order of the 58 preference statements regarding GP between elderly patients and younger patients. Elderly patients find 'good expertise of GP', 'no conflicting information' and 'good cooperation' important quality aspects, just as the other age groups. In this perspective, GPs must pay attention to the same quality aspects for the elderly patients as for the youngest patients.

However, the present study showed differences in the number of preference statements which are categorized as 'very important' between the age groups. The elderly patients categorised the lowest number of preference statements as 'very important'. The fact that the oldest patients are milder has been confirmed by previous research [25] and may be attributed to an age effect. As the life-cycle theory states, age can influence people's beliefs, values and attitudes regarding health care. The oldest patients become dependent, disabled and develop a loss of self-confidence, which may result, for instance, in less motivation to participate in shared decision making or active information seeking [26]. As a consequence, it may not be necessary to prepare health care providers for an upcoming critical patient group as younger patients grow older.

The present study demonstrated that patient characteristics and practice location did in most cases not confound the significant relationship between age and preference score. Only for five preference statements the 
Table 2 Preference scores and ranking order for the 58 preference statements for the four age groups

\begin{tabular}{|c|c|c|c|c|c|c|c|c|}
\hline \multirow[b]{2}{*}{ Preference statements } & \multicolumn{2}{|l|}{$\begin{array}{l}\text { 1. Patients } \\
0-30 \text { years }\end{array}$} & \multicolumn{2}{|c|}{$\begin{array}{l}\text { 2. Patients } \\
\text { 30-51 years }\end{array}$} & \multicolumn{2}{|c|}{$\begin{array}{l}\text { 3. Patients } \\
51-75 \text { years }\end{array}$} & \multicolumn{2}{|c|}{$\begin{array}{l}\text { 4. Patients } 75 \text { years } \\
\text { and older }\end{array}$} \\
\hline & $\begin{array}{l}\% \text { Very } \\
\text { important }\end{array}$ & $\begin{array}{l}\text { Rank } \\
\text { order }\end{array}$ & $\begin{array}{l}\% \text { Very } \\
\text { important }\end{array}$ & $\begin{array}{l}\text { Rank } \\
\text { order }\end{array}$ & $\begin{array}{l}\% \text { Very } \\
\text { important }\end{array}$ & $\begin{array}{l}\text { Rank } \\
\text { order }\end{array}$ & $\begin{array}{l}\% \text { Very } \\
\text { important }\end{array}$ & $\begin{array}{l}\text { Rank } \\
\text { order }\end{array}$ \\
\hline Good expertise of GP & 68.9 & 2 & 74.0 & 1 & 73.6 & 1 & 67.8 & 1 \\
\hline HCP does not give conflicting information* & $59.2^{4}$ & 5 & $60.3^{4}$ & 4 & $58.5^{4}$ & 4 & $48.3^{123}$ & 2 \\
\hline Good cooperation between $\mathrm{OHCP}$ and GP* & $56.1^{4}$ & 7 & $56.4^{4}$ & 5 & $58.0^{4}$ & 3 & $44.9^{123}$ & 3 \\
\hline GP gives understandable explanation regarding results & $55.1^{4}$ & 6 & $53.1^{4}$ & 6 & $54.1^{4}$ & 5 & $44.9^{123}$ & 4 \\
\hline GP takes me seriously** & $64.0^{34}$ & 3 & $60.4^{34}$ & 3 & $51.6^{124}$ & 6 & $43.2^{123}$ & 5 \\
\hline Privacy in examination room** & $69.9^{4}$ & 1 & $66.7^{4}$ & 2 & $64.8^{4}$ & 2 & $47.1^{123}$ & 6 \\
\hline GP must give information on side-effects medicine ${ }^{* *}$ & $26.2^{234}$ & 30 & $34.4^{14}$ & 30 & $37.3^{1}$ & 20 & $44.2^{12}$ & 7 \\
\hline $\mathrm{OHCP}$ redirects in time $\mathrm{e}^{* *}$ & $54.5^{4}$ & 9 & $53.0^{4}$ & 7 & $54.1^{4}$ & 7 & $38.8^{123}$ & 8 \\
\hline GP listens carefully** & $55.1^{34}$ & 4 & $50.5^{34}$ & 8 & $41.1^{124}$ & 10 & $32.7^{123}$ & 9 \\
\hline GP must give information regarding different treatments & 43.3 & 13 & 42.9 & 10 & $44.5^{4}$ & 8 & $34.6^{3}$ & 10 \\
\hline OHCP must have good expertise & 40.9 & 18 & 42.2 & 15 & $43.1^{4}$ & 13 & $34.3^{3}$ & 11 \\
\hline Good diagnosis of assistant & 39.9 & 17 & 45.7 & 12 & 44.2 & 12 & 39.1 & 12 \\
\hline Good accessibility of practice & $46.6^{3}$ & 15 & 39.8 & 18 & $39.3^{1}$ & 15 & 38.8 & 13 \\
\hline Treatment should reduce problems & 33.0 & 21 & $30.9^{3}$ & 29 & $36.8^{2}$ & 16 & 30.7 & 14 \\
\hline GP gives understandable explanation** & $42.8^{34}$ & 14 & $40.2^{4}$ & 13 & $35.8^{1}$ & 14 & $28.8^{12}$ & 15 \\
\hline GP needs to tell me what I want to know** & $50.2^{34}$ & 10 & $43.6^{4}$ & 9 & $42.0^{14}$ & 9 & $32.4^{123}$ & 16 \\
\hline Helpful staff & 33.6 & 19 & 33.5 & 17 & 30.3 & 17 & 26.2 & 17 \\
\hline GP Practice must be clean** & $40.1^{24}$ & 20 & $31.5^{1}$ & 24 & $35.6^{4}$ & 18 & $26.2^{13}$ & 18 \\
\hline Quick consult with own GP & $21.9^{3}$ & 33 & 27.1 & 32 & $28.7^{1}$ & 27 & 26.1 & 19 \\
\hline OHCP must take me seriously** & $39.2^{34}$ & 16 & $35.2^{34}$ & 16 & $29.1^{124}$ & 19 & $19.8^{123}$ & 20 \\
\hline GP has attention for personal situation & 31.5 & 32 & $33.3^{4}$ & 27 & 30.6 & 31 & $25.0^{2}$ & 21 \\
\hline OHCP must give understandable explanation & $28.6^{4}$ & 22 & 25.8 & 28 & 23.5 & 29 & $19.0^{1}$ & 22 \\
\hline Possibility to call $A H G P C^{*}$ & $16.3^{234}$ & 39 & $22.8^{13}$ & 38 & $30.4^{12}$ & 34 & $27.7^{1}$ & 23 \\
\hline Consultation within 24 hours** & $30.0^{3}$ & 24 & $36.2^{34}$ & 22 & $43.7^{124}$ & 11 & $27.1^{23}$ & 24 \\
\hline Good assistance on telephone & 24.4 & 23 & $25.0^{4}$ & 26 & 22.8 & 38 & $18.4^{2}$ & 25 \\
\hline Respect of GP for patient ${ }^{* *}$ & $54.4^{234}$ & 8 & $43.1^{134}$ & 11 & $30.2^{124}$ & 24 & $22.6^{123}$ & 26 \\
\hline GP is prepared to talk regarding mistakes* & $24.4^{23}$ & 29 & $32.0^{1}$ & 23 & $35.4^{1}$ & 22 & 30.9 & 27 \\
\hline GP must motivate advice & 22.1 & 34 & 21.6 & 34 & 24.1 & 35 & 23.5 & 28 \\
\hline Good cooperation GP and OHCP & 21.6 & 37 & $23.9^{3}$ & 36 & 27.5 & 30 & 23.8 & 29 \\
\hline Privacy at desk & 25.2 & 38 & 27.3 & 40 & 29.1 & 40 & 29.3 & 30 \\
\hline GP must help me find my way in health care ${ }^{* *}$ & $17.3^{34}$ & 45 & $19.0^{34}$ & 42 & $25.7^{12}$ & 38 & $25.9^{12}$ & 31 \\
\hline Respect of assistant ${ }^{* *}$ & $44.2^{234}$ & 11 & $32.9^{134}$ & 20 & $26.8^{12}$ & 31 & $20.9^{12}$ & 32 \\
\hline OHCP listens carefully & $25.5^{4}$ & 27 & $23.2^{4}$ & 33 & 22.1 & 36 & $15.7^{12}$ & 33 \\
\hline Respect of HCP for patient ${ }^{* *}$ & $42.1^{34}$ & 12 & $37.1^{34}$ & 14 & $28.1^{124}$ & 23 & $16.3^{123}$ & 34 \\
\hline GP must have sufficient time for patient** & $29.1^{4}$ & 24 & $28.0^{4}$ & 25 & 23.3 & 28 & $17.6^{12}$ & 35 \\
\hline GP attention for emotional causes of health problems & 31.5 & 25 & $35.4^{4}$ & 19 & $34.6^{4}$ & 21 & $25.6^{23}$ & 36 \\
\hline GP must help prevent disease & 18.4 & 49 & $17.7^{3}$ & 43 & $22.2^{2}$ & 43 & 17.1 & 37 \\
\hline GP gives room for participation in decision-making** & $28.3^{2}$ & 28 & $35.7^{14}$ & 21 & $32.3^{4}$ & 25 & $22.9^{23}$ & 38 \\
\hline Enough practice information available * & $17.0^{3}$ & 35 & 21.0 & 31 & $24.2^{14}$ & 33 & $17.4^{3}$ & 39 \\
\hline OHCP has information on disease history & 19.6 & 44 & 18.7 & 47 & 22.2 & 46 & 17.4 & 40 \\
\hline GP pays attention to emotional problems* & $15.9^{23}$ & 43 & $22.0^{1}$ & 35 & $23.2^{1}$ & 37 & 17.6 & 41 \\
\hline OHCP must spend sufficient time & $20.1^{4}$ & 31 & $18.1^{4}$ & 39 & 16.4 & 41 & $10.8^{12}$ & 42 \\
\hline
\end{tabular}


Table 2 Preference scores and ranking order for the $\mathbf{5 8}$ preference statements for the four age groups (Continued)

\begin{tabular}{|c|c|c|c|c|c|c|c|c|}
\hline OHCP wants to talk regarding mistakes * & 18.9 & 43 & $24.0^{4}$ & 37 & $24.2^{4}$ & 39 & $15.8^{23}$ & 43 \\
\hline OHCP must help prevent disease ${ }^{* *}$ & 17.4 & 47 & $15.1^{3}$ & 50 & $23.3^{24}$ & 47 & $14.8^{3}$ & 44 \\
\hline OHCP must motivate advice ${ }^{* *}$ & $17.7^{4}$ & 36 & $15.9^{34}$ & 44 & $22.2^{24}$ & 42 & $8.5^{123}$ & 45 \\
\hline GP must redirect when I think it is necessary * & $18.4^{3}$ & 51 & $18.3^{3}$ & 48 & $24.2^{12}$ & 50 & 23.3 & 46 \\
\hline OHCP gives room participation in decision making* & 18.1 & 40 & $22.3^{4}$ & 41 & $21.0^{4}$ & 44 & $12.5^{23}$ & 47 \\
\hline Assistant must spend enough time & $16.3^{4}$ & 42 & 14.0 & 45 & 14.6 & 49 & $9.7^{1}$ & 48 \\
\hline Good (fast) contact on telephone ${ }^{* *}$ & $12.0^{34}$ & 54 & $13.0^{34}$ & 49 & $22.5^{12}$ & 48 & $22.3^{12}$ & 49 \\
\hline Enough seating in general practice & 9.3 & 53 & 8.1 & 51 & 8.4 & 52 & 6.8 & 50 \\
\hline Quick access to consultation * & $11.7^{3}$ & 48 & 17.4 & 43 & $18.7^{1}$ & 25 & 13.1 & 51 \\
\hline OHCP must pay attention to emotional problems** & $12.2^{3}$ & 52 & $12.0^{3}$ & 53 & $18.3^{124}$ & 50 & $9.6^{3}$ & 52 \\
\hline Direct contact with GP & 12.8 & 55 & 12.5 & 56 & 15.3 & 54 & 15.1 & 53 \\
\hline Information on health problems available in practice & $14.1^{4}$ & 50 & 11.3 & 54 & 13.1 & 53 & $8.00^{1}$ & 54 \\
\hline Helped within 15 minutes after the agreed time ${ }^{* *}$ & $17.3^{234}$ & 46 & $12.3^{14}$ & 52 & $9.5^{1}$ & 55 & $7.3^{12}$ & 55 \\
\hline Favourable practice hours & 5.7 & 56 & 7.2 & 55 & 6.6 & 56 & 8.0 & 56 \\
\hline GP prescribes medicine when I think it is necessary & 8.8 & 58 & 6.9 & 58 & 9.4 & 57 & 9.2 & 57 \\
\hline Possibility to go to $A H G P C$ & 7.1 & 57 & 6.9 & 57 & 7.8 & 58 & 8.6 & 58 \\
\hline
\end{tabular}

$O H C P=$ the Other Health Care Provider within the general practice.

$A H G P C=$ After Hours General Practitioner Clinic.

* $=p<0.05 ;{ }^{* *}=p<0.01$.

factor 'education' confounded the relationship between age and preference score. This finding may indicate that older patients with a higher level of education, in some cases, have other preferences regarding quality of GP care than older patients with a lower education level. This may mean that as highly-educated patients grow older, GPs have to be aware of their divergent needs and desires. In this sense, the difference in preference score for the different age groups can be a cohort effect. In the future, GPs may encounter more well-educated elderly people with preferences comparable to those of younger patients [12]. However, education only influenced the relationship for 5 of the 31 preference statements entailing redirection to medical specialists, assistants to prevent diseases, cooperation between health-care providers, conflicting information and attention for emotional problems.

Not only the mean age of the GP's patient population will change, but also the health care offered by the GP. As patients grow older, GP care will shift from cure to care. Also, the GP care in the Netherlands for patients

Table 3 Mean number of statements which are 'very important' for the different age groups

\begin{tabular}{llll}
\hline Age groups & $\begin{array}{l}\text { Mean number of statements } \\
\text { which are 'very important' }\end{array}$ & SD & N \\
\hline 0-30 years & 17.2 & 12.1 & 233 \\
30-51 years & 17.7 & 13.9 & 514 \\
51-75 years & 18.1 & 14.0 & 542 \\
75 years and older & 14.2 & 11.2 & 148 \\
\hline
\end{tabular}

with a chronic disease will shift to a more patientcentred focus and different disciplines and health-care organisations will be stimulated to cooperate. These changes may change patients' opinions regarding GP care in the future [27]. Therefore, research into the preferences regarding GP care for different patient groups should be repeated in the future.

A limitation of this study, given the number of comparisons made and statistical tests performed, is the issue of multiple testing. In short, the multiple testing issue entails that when a series of comparisons are performed while in reality there are no differences, $5 \%$ of these test will show a significant difference solely due to chance. Statistical solutions to this problem, such as the Bonferroni correction for example, generally reduce power. Accordingly, we chose not to apply a statistical correction for multiple comparisons, but to address this issue when interpreting the results. In this context, it is worth noting that although we found much more significant results than could be expected based on chance alone, a small number of the significant results may potentially be a result of the number of tests performed.

A second limitation is the arbitrary approach by which the age groups have been categorised, especially, the age group 0-30 years old which include preferences from parents with young children with preferences from young adults. Nevertheless, our data show that the group of ' $0-30$ years old' had the most significant differences in preference scores $(n=26)$ with the group of '75 years and older'. For the group of ' $30-50$ years old', the most significant differences $(n=28)$ are also with the 
Table 4 Results nested logistic regression analyses for 5 preference statements for which confounders influence the relationship between age and preference score

Odds ratio Std. Err. z $95 \%$ conf. Interval

Preference statement 36: GP must redirect me to a medical specialist when I think it is necessary

Reference category $51-75$ years

Model 1

$\begin{array}{llllll}75 \text { years and older } & 0.97 & 0.2 & 0.87 & 0.65 & 1.44 \\ \text { 30-51 years } & 0.72 & 0.1 & 0.02 & 0.55 & 0.95 \\ \text { 0-30 years } & 0.7 & 0.13 & 0.05 & 0.49 & 1 \\ \text { Model 2 } & & & & & \\ \text { 75 years and older } & 0.9 & 0.18 & 0.61 & 0.6 & 1.35 \\ \text { 30-51 years } & 0.77 & 0.11 & 0.06 & 0.58 & 1.02 \\ \text { 0-30 years } & 0.72 & 0.13 & 0.08 & 0.5 & 1.04 \\ \text { Gender } & 0.93 & 0.12 & 0.58 & 0.73 & 1.19 \\ \text { Education } & 0.81 & 0.07 & 0.02 & 0.68 & 0.96\end{array}$

Preference statement 57: The OHCP* must assist me to prevent diseases or to improve my health

Reference category 0-30 years

Model 1

$\begin{array}{llllll}75 \text { years and older } & 0.9 & 0.26 & 0.7 & 0.51 & 1.57 \\ \text { 51-75 years } & 1.57 & 0.31 & 0.03 & 1.06 & 2.33 \\ \text { 30-51 years } & 0.94 & 0.2 & 0.77 & 0.62 & 1.42 \\ \text { Model 2 } & & & & & \\ \text { 75 years and older } & 0.76 & 0.22 & 0.35 & 0.43 & 1.35 \\ \text { 51-75 years } & 1.46 & 0.3 & 0.07 & 0.98 & 2.17 \\ \text { 30-51 years } & 0.97 & 0.21 & 0.9 & 0.64 & 1.48 \\ \text { Gender } & 1.14 & 0.16 & 0.35 & 0.87 & 1.49 \\ \text { Education } & 0.73 & 0.07 & 0 & 0.6 & 0.89\end{array}$

Preference statement 59 The OHCP must pay attention to emotional problems

Reference category: 0-30 years

Model 1

$\begin{array}{llllll}\text { 75 years and older } & 0.87 & 0.29 & 0.68 & 0.45 & 1.67 \\ \text { 51-75 years } & 1.71 & 0.39 & 0.02 & 1.09 & 2.68 \\ \text { 30-51 years } & 1.1 & 0.26 & 0.69 & 0.7 & 1.76 \\ \text { Model 2 } & & & & & \\ \text { 75 years and older } & 0.69 & 0.23 & 0.28 & 0.36 & 1.34 \\ \text { 51-75 years } & 1.57 & 0.36 & 0.05 & 1 & 2.47 \\ \text { 30-51 years } & 1.16 & 0.28 & 0.54 & 0.72 & 1.86 \\ \text { Gender } & 0.99 & 0.15 & 0.97 & 0.74 & 1.34 \\ \text { Education } & 0.64 & 0.07 & 0 & 0.51 & 0.79\end{array}$

Preference statement 62: The OHCP must collaborate well with GP Reference category $51-75$ years

Model 1

$\begin{array}{llllll}75 \text { years and older } & 0.7 & 0.13 & 0.047 & 0.49 & 0.99 \\ 30-51 \text { years } & 0.97 & 0.12 & 0.82 & 0.77 & 1.23\end{array}$

Table 4 Results nested logistic regression analyses for 5 preference statements for which confounders influence the relationship between age and preference score (Continued)

\begin{tabular}{llllll}
\hline 0-30 years & 0.96 & 0.15 & 0.78 & 0.71 & 1.3 \\
Model 2 & & & & & \\
75 years and older & 0.74 & 0.13 & 0.1 & 0.52 & 1.06 \\
30-51 years & 0.9 & 0.11 & 0.39 & 0.7 & 1.15 \\
0-30 years & 0.91 & 0.14 & 0.53 & 0.67 & 1.23 \\
Gender & 0.91 & 0.09 & 0.4 & 0.74 & 1.13 \\
Education & 1.23 & 0.1 & 0.01 & 1.07 & 1.43
\end{tabular}

Preference statement 63: The OHCP must not give conflicting information Reference category $0-30$ years

Model 1

$\begin{array}{llllll}75 \text { years and older } & 0.66 & 0.12 & 0.02 & 0.46 & 0.95 \\ \text { 51-75 years } & 0.91 & 0.11 & 0.43 & 0.71 & 1.16 \\ 30-51 \text { years } & 0.95 & 0.15 & 0.73 & 0.7 & 1.29\end{array}$

Model 2

\begin{tabular}{llllll}
75 years and older & 0.75 & 0.14 & 0.12 & 0.52 & 1.08 \\
51-75 years & 0.98 & 0.12 & 0.86 & 0.76 & 1.25 \\
30-51 years & 0.97 & 0.15 & 0.84 & 0.71 & 1.32 \\
Gender & 0.89 & 0.1 & 0.27 & 0.72 & 1.1 \\
Education & 1.2 & 0.09 & 0.01 & 1.04 & 1.4 \\
\hline *OHCP The other health care provider.
\end{tabular}

${ }^{*} \mathrm{OHCP}=$ The other health care provider.

group '75 years and older' and the same is true for the group ' $50-75$ years old' $(\mathrm{n}=23)$. So, the most divergent group is the age group ' 75 years and older'. Previous research using other age groups confirmed that preference scores differ between age groups. In addition, we found that generally the relationship between age and preference score is not significantly influenced by patient and practice characteristics.

Another aspect which has to be taken into account is the fact that patient preferences are influenced by the length of time that elapsed between the consultation and filling in the survey [28]. We have no information regarding the length of time elapsed between the consultation and the survey. However, our sample contained people who had visited their GP in the year preceding the survey and people who had not visited their GP in that year. Therefore, the preference scores were not only influenced by recent experiences of our sample.

Lastly, our study did not investigate every possible patient or practice characteristic. For example, patients' religion may also influence the relationship between age and preference score. According to a systematic review, religion is most frequently found to influence patients' preferences [6]. However, our data set did not include this variable. 
One of the strengths of our research is the large number of preference statements which were investigated, that these preference statements were based on interviews and focus groups with patients and were approved by different health-care organisations. Moreover, our survey was developed using widely known and tested CQI-methodology [15] and also included preference statements regarding the other health care provider in GP care which is rather unique.

\section{Conclusion}

The present study investigated the preferences regarding general practice care of elderly patients and whether patient characteristics and practice location may confound the relationship between age and the categorisation of a preference score as very important. This study demonstrated that the preferences of elderly patients concerning GP care concern the same items as younger patients. However, their preferences are less strong, which cannot be ascribed to gender, education, perceived health, the number of GP contacts and practice location.

\section{Ethical approval}

Not required since published data were used.

\section{Competing interests}

The authors declare that they have no competing interests.

\section{Authors' contributions}

WAdGR, AJB, DdB and DHdB contributed to the design of this study. AJB was responsible for the subject of this study. WAdGR was responsible for the day-to-day management, the statistics and produced the first draft of the manuscript. All authors contributed to the write-up of this study. All authors read and approved the final manuscript.

\section{Acknowledgements}

We acknowledge NIVEL and the Dutch College of General Practitioners (NHG) for funding this research.

\section{Author details \\ ${ }^{1}$ Department of primary care organization, NIVEL: Netherlands Institute for Health Service Research, PO Box 1568, 3500 BN Utrecht, The Netherlands. 2Department of General Practice, University of Groningen, University Medical Center Groningen, 9713 AV Groningen, The Netherlands. ${ }^{3}$ Department of quality of care, NIVEL: Netherlands Institute for Health Service Research, the Dutch Centre for Consumer Experience in Health Care housed at NIVEL, PO Box 1568, 3500 BN Utrecht, The Netherlands. ${ }^{4}$ Department of Social and behavioural science, Tranzo Tilburg University, PO Box 90153, 5000 LE Tilburg, The Netherlands.}

Received: 7 January 2013 Accepted: 18 June 2013

Published: 25 June 2013

\section{References}

1. World Health Organization: Active ageing: towards age friendly primary health care. Geneva: World Health Organization; 2004

2. Van Oers JAM: Gezondheid op koers? Volksgezondheid Toekomst Verkenning 2002. Bilthoven: Rijksinstituut voor Volksgezondheid en Milieu; 2003 [Health on Course? The 2002 Dutch Public Health Status and Forecasts Report, 2003].

3. Van Lindert H, Droomers M, Westert GP: Tweede nationale studie naar ziekten en verrichtingen in de huisartsenpraktijk. Een kwestie van verschil. Verschillen in zelfgerapporteerde leefstijl, gezondheid en zorggebruik. [Second Dutch National Survey of General Practice; a matter of difference; differences in self-reported lifestyle, health and health use]. Utrecht: NIVEL; 2004.
4. Verheij RA, Van Dijk CE, Abrahamse H, Davids R, Van den Hoogen $H$, Braspenning J, Van Althuis T: Landelijk Informatienetwerk Huisartsenzorg. Feiten en cijfers over huisartsenzorg in Nederland. [National InformationNetwork GP care. Facts and figures about the GP care in the Netherlands]. Utrecht/Nijmegen: NIVEL/IQ; 2009. [http://www.nivel.nl/oc2/ page.asp?pageid=12688], bezocht op 5 maart 2010.

5. Wensing M, Jung HP, Mainz J, Olesen F, Grol R: A systematic review of the literature on patient priorities for general practice care. Part 1: description of the research domain. Social Science Medicine 1998, 47(10):1573-1588.

6. Jung HP, Baerveldt C, Olesen F, Grol R, Wensing M: Patient characteristics as predictors of primary health care preferences: a systematic literature analysis. Health Expect 2003, 6:160-181.

7. De Boer D, Delnoij D, Rademakers J: Do patient experiences on priority aspects of health care predict their global rating of quality of care? A study in five patient groups. Health Expect 2010, 13:285-297.

8. Smith C, Armstrong D: Comparison of criteria derived by government and patient for evaluating general practitioner services. Br Med J 1989 29:494-496.

9. Jung HP, Wensing M, Grol R: Aspects of general practice care, seen from the patients perspective. Huisarts en Wetenschap 1996, 39(13):594-599.

10. Al-Bashir M, Armstrong D: Preferences of healthy and ill patients for style of general practitioner care: implications for workload and financial incentives under the new contract. Br J Gen Pract 1991, 41:6-8.

11. Laurant MG, Hermens RP, Braspenning JC, Akkermans RP, Sibbald B, Grol RP: An overview of patients' preferences for, and satisfaction with, care provided by general practitioners and nurse practitioners. J Clin Nurs 2008, 17:2690-2698.

12. Rosen $P$, Anell A, Hjortsberg C: Patients views on choice and participation in primary health care. Health Policy 2001, 55:121-128.

13. Berkelmans PGJ, Berendsen AJ, Verhaak PFM, Van Der Meer K: Characteristics of general practice care: What do senior citizens value? A qualitative study. BMC Geriatrics 2010, 10(1):80-88.

14. Meuwissen LE, De Bakker DH: 'Consumer quality'-index huisartsenzorg meet patiëntervaringen en vergelijkt huisartsenpraktijken. Ned Tijdschr Geneeskd 2009, 153:1-7.

15. Sixma HJ, Delnoij DM, Stubbe JH, Triemstra AHM, et al: Handboek CQ/ meetinstrumenten: een handleiding voor de ontwikkeling en het gebruik van Consumer Quality Index (CQI) vragenlijsten. [Handbook CQI measuring instruments: a handbook for the development and use of Consumer Quality Index (CQI) questionnaires]. Utrecht: Centrum Klantervaring Zorg; 2007. versie 1, 22 maart.

16. Hargraves $J$, Hays RD, Cleary PD: Psychometric properties of the Consumer Assessment of Health Plans Study (CAHPS) 2.0 adult core survey. Health Serv Res 2003, 38:1509-27.

17. Carman KL, Short PF, Farley DO, Schnaier JA, Elliott DB, Gallagher PM: Epilogue: early lessons from CAHPS demonstrations and evaluations. Consumer Assessment of Health Plans Study. Med Care 1999, 37:MS97-105.

18. Hekkink CF, Sixma HJ, Wigersma L, Yzermans CJ, Van Der Meer JT, Bindels PJ, et al: QUOTE-HIV: an instrument for assessing quality of HIV care from the patients' perspective. Qual Saf Health Care 2003, 12:188-93.

19. Nijkamp MD, Sixma HJ, Afman H, Hiddema F, Koopmans SA, Van Den BB, et al: Quality of care from the perspective of the cataract patient. QUOTE cataract questionnaire. J Cataract Refract Surg 2002, 28:1924-31.

20. Sixma HJ, Kerssens JJ, Campen CV, Peters L: Quality of care from the patients' perspective: from theoretical concept to a new measuring instrument. Health Expect 1998, 1:82-95.

21. Van Campen C, Sixma HJ, Kerssens JJ, Peters L, Rasker JJ: Assessing patients' priorities and perceptions of the quality of health care: the development of the QUOTE-Rheumatic-Patients instrument. Br J Rheumatol 1998, 37:362-68.

22. Triemstra M, Winters $S$, Kool RB, Wiegers TA: Measuring client experiences in long-term care in the Netherlands: a pilot study with the consumer quality index long-term care. BMC Health Serv Res 2010, 10:95.

23. Westert GP, Berg Van Den MJ, Zwakhals SLN, De JD J, Verkleij H: Dutch health care performance report 2010. Bilthoven, The Netherlands: National Institute for Public Health and the Environment; 2010.

24. De Ven AHJ V d R-V: Handreiking, samenhangende zorg in de eerste lijn. Complexe ouderenzorg in verzorgingstehuis en thuis. [Guidance, coordinated care in primary care. Complex elderly care in nursing home and home]. Utrecht: LHV, KNMP, NHG, NWA; 2009 
25. Anell A, Rosen P, Hjortsberg C: Choice and participation in health services: a survey under of preferences among Swedish residents. Health Policy 1997, 40:157-168.

26. Inglehart R: Post-materialism in an environment of insecurity. American Political Science Review 1981, 75:880-900.

27. Wensing M, Grol R, Smits A, Van Montfort P: Hoe oordelen chronische zieken over de huisartsenzorg? [How do chronic sick judge GP care?]. Huisarts en Wetenschap 1996, 39(9):402-407.

28. Jung HP, Wensing M, De Wilt A, Olesen F, Goll R: Comparison of patients' preferences and evaluations regarding aspects of general practice care. Fam Pract 2000, 17:236-242.

doi:10.1186/1471-2296-14-90

Cite this article as: de Graaf-Ruizendaal et al:: Do patient and practice characteristics confound age-group differences in preferences for general practice care? A quantitative study. BMC Family Practice 2013 14:90.

\section{Submit your next manuscript to BioMed Central and take full advantage of:}

- Convenient online submission

- Thorough peer review

- No space constraints or color figure charges

- Immediate publication on acceptance

- Inclusion in PubMed, CAS, Scopus and Google Scholar

- Research which is freely available for redistribution 